\title{
Thiorhodospira sibirica gen. nov., sp. nov., a new alkaliphilic purple sulfur bacterium from a Siberian soda lake
}

\author{
Irina Bryantseva, ${ }^{1}$ Vladimir M. Gorlenko, ${ }^{1}$ Elena I. Kompantseva, ${ }^{1}$ \\ Johannes F. Imhoff, ${ }^{2}$ Jörg Süling ${ }^{2}$ and Lubov' Mityushina ${ }^{1}$
}

\author{
Author for correspondence: Johannes F. Imhoff. Tel: +49431 6973850. Fax: +49431565876. \\ e-mail: jimhoff@ifm.uni-kiel.de
}

\footnotetext{
1 Institute of Microbiology, Russian Academy of Sciences, pr. 60-letiya Oktyabrya 7 k. 2, Moscow 117811, Russia

2 Institut für Meereskunde, Abt. Marine Mikrobiologie, Düsternbrooker Weg 20, 24105 Kiel, Germany
}

\begin{abstract}
A new purple sulfur bacterium was isolated from microbial films on decaying plant mass in the near-shore area of the soda lake Malyi Kasytui (pH 9.5, 0.2\% salinity) located in the steppe of the Chita region of south-east Siberia. Single cells were vibrioid- or spiral-shaped (3-4 $\mu \mathrm{m}$ wide and 7-20 $\mu \mathrm{m}$ long) and motile by means of a polar tuft of flagella. Internal photosynthetic membranes were of the lamellar type. Lamellae almost filled the whole cell, forming strands and coils. Photosynthetic pigments were bacteriochlorophyll $a$ and carotenoids of the spirilloxanthin group. The new bacterium was strictly anaerobic. Under anoxic conditions, hydrogen sulfide and elemental sulfur were used as photosynthetic electron donors. During growth on sulfide, sulfur globules were formed as intermediate oxidation products. They were deposited outside the cytoplasm of the cells, in the peripheral periplasmic space and extracellularly. Thiosulfate was not used. Carbon dioxide, acetate, pyruvate, propionate, succinate, fumarate and malate were utilized as carbon sources. Optimum growth rates were obtained at $\mathbf{p H ~} 9.0$ and optimum temperature was $30{ }^{\circ} \mathrm{C}$. Good growth was observed in a mineral salts medium containing $\mathbf{5} \mathbf{g}$ sodium bicarbonate $\mathrm{I}^{-1}$ without sodium chloride. The new bacterium tolerated up to $60 \mathrm{~g}$ sodium chloride $\mathrm{I}^{-1}$ and up to $80 \mathrm{~g}$ sodium carbonates $\mathrm{I}^{-1}$. Growth factors were not required. The DNA G+C composition was $56 \cdot 0-57 \cdot 4 \mathrm{~mol} \%$. Based on physiological, biochemical and genetic characteristics, the newly isolated bacterium is recognized as a new species of a new genus with the proposed name Thiorhodospira sibirica.
\end{abstract}

Keywords: Ectothiorhodospiraceae, purple sulfur bacteria, Thiorhodospira sibirica gen. nov., sp. nov.

\section{INTRODUCTION}

Purple sulfur bacteria comprise a compact phylogenetic subdivision of the $\gamma$-Proteobacteria (Woese et al., 1985; Stackebrandt et al., 1988). They are divided into two families, Chromatiaceae, accumulating intracellular elemental sulfur, and Ectothiorhodospiraceae, depositing sulfur outside the cells (Imhoff, 1984, 1995). According to $16 \mathrm{~S}$ rDNA sequence similarities, both families form genetically distinct groups among the $\gamma$-Proteobacteria (Imhoff \& Süling, 1996; Imhoff et al., 1998). Purple sulfur bacteria are widespread in the plankton of stratified lakes and in

The EMBL accession number for the $16 \mathrm{~S}$ rDNA sequence of strain $A 12^{\top}$ is AJ006530. the benthos of all kinds of aquatic habitats where they often develop in cyanobacterial mats and in films on decaying near-shore plant mass (Gorlenko et al., 1983; van Gemerden \& Mas, 1995). They are commonly found in freshwater lakes and springs as well as in marine and hypersaline habitats. van Niel (1931) noted that purple sulfur bacteria prefer to grow in alkaline environments. However, pure cultures of most species show optimum growth rates at $\mathrm{pH}$ 6.5-7.6 (Pfennig \& Trüper, 1974). Only species of the Ectothiorhodospiraceae, particularly those isolated from saline soda lakes, grow well at $\mathrm{pH} 9.0$ and may be considered as alkaliphiles (Imhoff et al., 1979; Imhoff, 1992).

Traditionally, purple sulfur bacteria are differentiated by their morphological properties. The shape and size 
of the cells, their motility, the occurrence of gas vesicles and the localization of sulfur globules were used by Winogradsky (1888) as a basis for the systematics of these bacteria. Later, the type of internal membranes and the pigment composition were used as additional properties for their taxonomic identification (Pfennig \& Trüper, 1974). Current data of genetic relations, primarily those on $16 \mathrm{~S}$ rDNA sequences, showed that phenotypically similar species can be rather unrelated genetically (Imhoff et al., 1998). Therefore, for identification of new isolates of purple sulfur bacteria, consideration should be given to both phenotypic properties and genetic relatedness.

During investigation of phototrophic communities in the littoral areas of soda lakes in the Chita and Buryatia regions (south-east Siberia), large spiralshaped cells of purple sulfur bacteria were detected that formed brownish-red colonies in sulfide-containing agar medium at $\mathrm{pH} 9 \cdot 0-9 \cdot 5$. A pure culture of such a bacterium was isolated from a sample of Lake Malyi Kasytui. The present paper reports the fine structure, physiological properties, pigment composition and taxonomic position of this new spiral-shaped purple sulfur bacterium.

\section{METHODS}

Source of organism. The bacterium (strain $\mathrm{A} 12^{\mathrm{T}}$ ) was isolated from Lake Malyi Kasytui located in the Chita region of south-east Siberia, Russia. The lake is a shallow soda reservoir with a total salt content of $2 \mathrm{~g} \mathrm{l}^{-1}$ and $\mathrm{pH} \mathrm{9.5.}$ Phototrophic purple bacteria developed in a shallow nearshore area on the surface of decaying plant biomass as a purple layer below a blue-green surface film of cyanobacteria.

Isolation and cultivation. Pure cultures of phototrophic purple bacteria were obtained by repeated deep agar $(0.8 \%)$ dilution series. The basal medium used for isolation and cultivation of the bacteria contained $\left(1^{-1}\right.$ distilled water $)$ : $0.5 \mathrm{~g} \mathrm{KH}_{2} \mathrm{PO}_{4} ; 0.5 \mathrm{~g} \mathrm{NH}_{4} \mathrm{Cl} ; 0.5 \mathrm{~g} \mathrm{NaCl} ; 0.2 \mathrm{~g} \mathrm{MgCl}_{2} .6 \mathrm{H}_{2} \mathrm{O}$; $0.05 \mathrm{~g} \mathrm{CaCl}_{2} .2 \mathrm{H}_{2} \mathrm{O} ; 2.5 \mathrm{~g} \mathrm{NaHCO}_{3} ; 2.5 \mathrm{~g} \mathrm{Na}_{2} \mathrm{CO}_{3} ; 0.5 \mathrm{~g}$ sodium acetate; $0.5 \mathrm{~g}$ sodium malate; $0.1 \mathrm{~g}$ yeast extract; $0.7 \mathrm{~g} \mathrm{Na}_{2} \mathrm{~S} .9 \mathrm{H}_{2} \mathrm{O}$; and $1 \mathrm{ml}$ trace element solution SL8. The $\mathrm{pH}$ was adjusted to $9 \cdot 0-9 \cdot 5$. Purity of cultures was checked microscopically and by the absence of colourless colonies in the agar medium.

Cultures were grown phototrophically in $50 \mathrm{ml}$ screw-capped bottles at $25-30^{\circ} \mathrm{C}$ and a light intensity of $2000 \mathrm{~lx}$. Repeated addition of sulfide feeding solution was used to obtain high cell yields. Carbon sources tested were added at a concentration of 0.3 or $0.5 \mathrm{~g} \mathrm{l}^{-1}$. Growth was followed by measuring $\mathrm{OD}_{650}$ or by quantifying the pigment content in acetone extracts at $770 \mathrm{~nm}$ with a KF-3 photometer.

Microscopy. Cell morphology was studied by light and electron microscopy. Intact cells were stained with $1 \%$ phosphotungstic acid. Ultrathin sections were prepared as described earlier (Ryter \& Kellenberger, 1958).

Pigment and sulfur analyses. Absorption spectra of living cells were recorded with a SPh-56 spectrophotometer and the cells were suspended in $50 \%$ glycerol for these measurements. In addition, pigments were extracted with acetone and absorption spectra of these extracts were recorded. Carotenoid composition was analysed by HPLC as de- scribed earlier (Sidorova et al., 1998). Sulfide was measured colorimetrically (Trüper \& Schlegel, 1964) and sulfate was determined turbidometrically (Dodgson, 1961).

DNA analysis. DNA was isolated by the method of Marmur (1961) and the DNA G + C composition was determined by thermal denaturation (A. M. Lysenko, according to Owen et al., 1969). Cell material for $16 \mathrm{~S}$ rDNA sequencing was taken from 1-2 ml well-grown liquid cultures. DNA was extracted and purified by using the QIAGEN genomic DNA buffer set. PCR amplification and 16S rDNA sequencing was done as described earlier (Imhoff et al., 1998). Recombinant Taq polymerase was used for PCR, which was started with the following primers: $5^{\prime}$ GTTTGATCCTGGCTCAG $3^{\prime}$ and 5' TACCTTGTTACGACTTCA 3' (positions 11-27 and 1489-1506, respectively, according to the Escherichia coli $16 \mathrm{~S}$ rRNA numbering of the International Union of Biochemistry). Sequences were obtained by cycle sequencing with the SequiTherm sequencing kit (Biozym) and the chaintermination reaction (Sanger et al., 1977) using an automated laser fluorescence sequencer. Sequences were aligned using the CLUSTAL w program (Thompson et al., 1994). The alignment length was at position 29-1381 according to $E$. coli numbering. The distance matrix was calculated on the basis of the algorithm according to Jukes \& Cantor (1969) with the DNADIST program within the PHYLIP package (Felsenstein, 1989). The FITCH program in the PHYLIP package fitted a tree to the evolutionary distances.

\section{RESULTS}

\section{Natural habitat and isolation}

Samples were collected from thin cyanobacterial mats and microbial films formed on the sediment surface or on decaying plant mass in littoral areas of five soda lakes in south-east Siberia: Lake Malyi Kasytui, Lake Ilim Torum, Lake Verkhnee Beloe, Lake Nizhnee Beloe and Nuhe Nur. The salinity was low in all lakes $\left(2 \cdot 0-10 \cdot 0 \mathrm{~g}^{-1}\right)$ and the $\mathrm{pH}$ range was $9 \cdot 2-9 \cdot 7$. Microbial films were dominated by unicellular cyanobacteria resembling Synechococcus species and filamentous green Oscillochloris species. In addition, purple sulfur bacteria resembling species of Amoebobacter, Thiocapsa or Thiolamprovum (non-motile cocci containing gas vesicles) and Allochromatium or Marichromatium species (small, motile rod-shaped bacteria without gas vesicles) as well as purple non-sulfur bacteria resembling Rhodobacter and Rhodovulum species were quite abundant. Spiral-shaped bacteria of the Ectothiorhodospiraceae (depositing sulfur outside the cells) and Chromatiaceae (depositing sulfur inside the cells) were much less numerous (by approx. three orders of magnitude).

Inoculation and incubation of all samples studied in solid agar medium yielded spiral-shaped purple sulfur bacteria. Strain $A 12^{T}$ was isolated in a pure culture by repeated transfers of separate colonies grown from samples inoculated with microbial films from Lake Malyi Kasytui. In agar medium, this new purple sulfur bacterium formed typical brownish-red colonies with diffused edges. During growth in liquid medium, the colour of bacteria changed from brownish-red (cultures with elemental sulfur) to dark red (cultures free of elemental sulfur). 


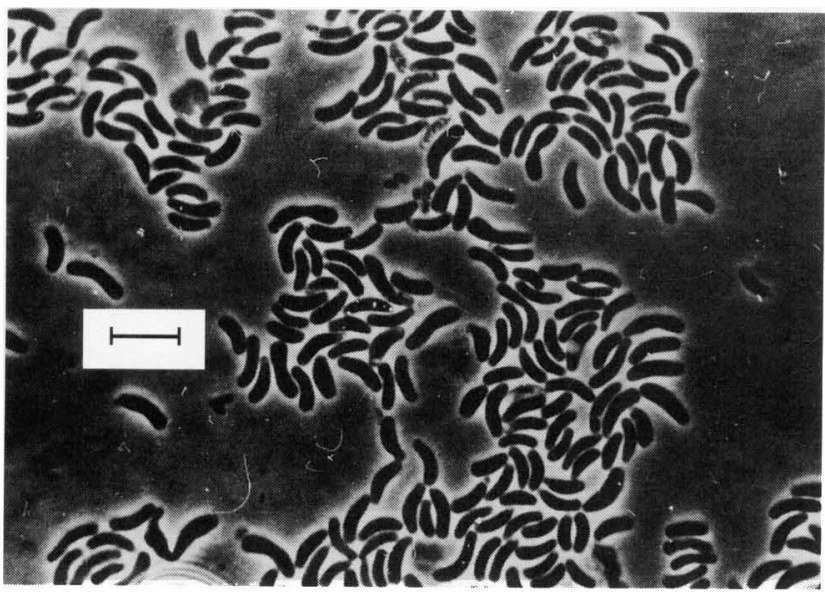

Fig. 1. Phase-contrast photomicrograph of strain $A 12^{\top}$ grown photoautotrophically after consumption of elemental sulfur. Bar, $20 \mu \mathrm{m}$.

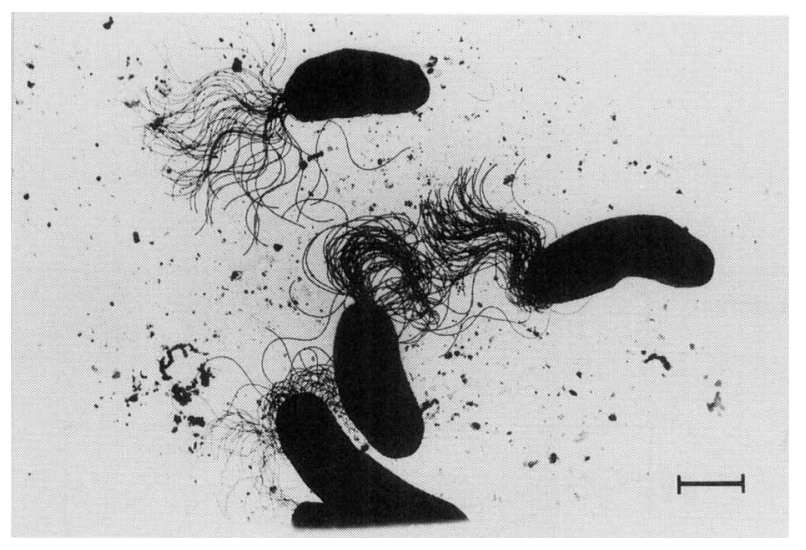

Fig. 2. Negatively stained cells of strain $A 12^{\top}$ showing the polar tuft of flagella. Bar, $3 \mu \mathrm{m}$.

\section{Morphology and fine structure}

Individual cells of strain $\mathrm{A} 12^{\mathrm{T}}$ were vibrioid- or spiralshaped, 3-4 $\mu \mathrm{m}$ wide and 7-20 $\mu \mathrm{m}$ long (Fig. 1). Cells multiplied by binary fission with septum formation. Cells were motile by a polar tuft of flagella (Fig. 2). In cultures grown at suboptimal $\mathrm{pH}$ values, cells of abnormal shape were observed: large cells of irregular form were seen at $\mathrm{pH} 7.5$ and thread-like cells were seen at $\mathrm{pH} 10 \cdot 5$. The cell wall was thin and of the Gram-negative type. Internal photosynthetic membranes (chromatophores) were represented by long strands of lamellae that pierced the whole cell lengthways leaving just islets of the cytoplasm (Fig. 3). Lamellae could also form coils occupying the periphery of the cells as in Rhodocista centenaria or in Rhodopseudomonas palustris, but were not arranged in regular stacks as in known Ectothiorhodospira species. Globules of elemental sulfur were formed. They appeared outside the cells, peripherally attached to

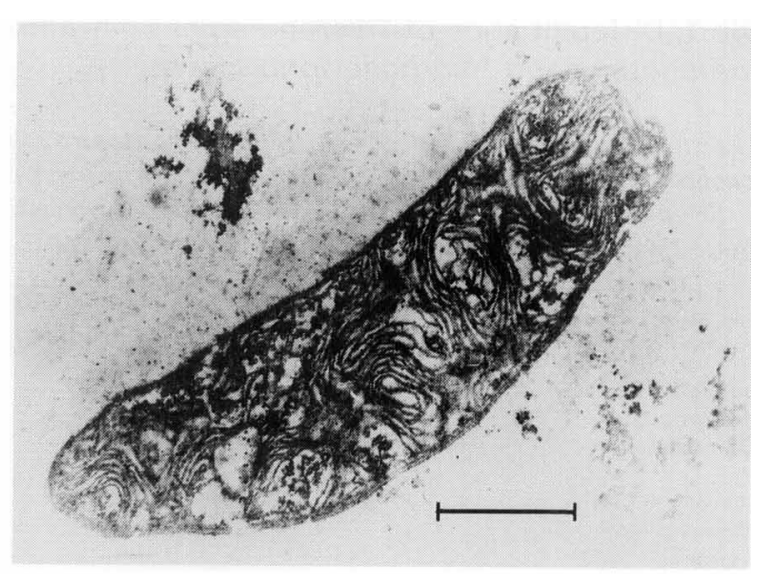

Fig. 3. Electron micrograph of ultrathin sections of strain $A 12^{\top}$ showing lamellar internal membrane structures. Bar, $2 \mu \mathrm{m}$.

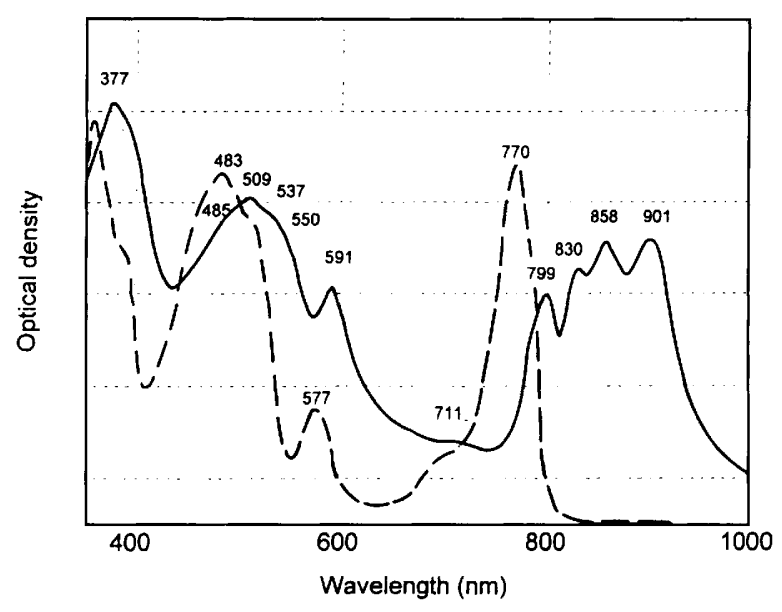

Fig. 4. Absorption spectra of strain $\mathrm{A} 12^{\mathrm{T}}$; whole cell suspensions in $50 \%$ glycerol (continuous line) and acetone extracted pigments (dashed line).

them, and regularly can be seen in the peripheral periplasmic part of the cells in such a way that the impression could be given that they are located inside the cytoplasm. Upon careful microscopic inspection, it was observed that sulfur globules were never seen in the central cytoplasmic part of the cells but only in the peripheral periplasmic part.

\section{Pigments}

Strain $\mathrm{A} 12^{\mathrm{T}}$ contains bacteriochlorophyll $a$. In the IR region, the absorption spectrum of intact cells exhibited four maxima of bacteriochlorophyll $a$ at 799, 830,858 and $901 \mathrm{~nm}$ (Fig. 4). In the acetone extract, its main absorption maximum was at $770 \mathrm{~nm}$ (Fig. 4). Carotenoid analysis identified anhydrorhodovibrin, rhodopin and spirilloxanthin as the major carotenoids of strain $\mathrm{A} 12^{\mathrm{T}}$, which comprised $91 \%$ of the total carotenoid content. Anhydrorhodovibrin was the predominant component $(37.6 \%)$, followed in quantity 
Table 1. Differentiation of Thiorhodospira sibirica from representative type strains of Ectothiorhodospira, Halorhodospira and Thiorhodovibrio species

1, Thiorhodospira sibirica $\left(\mathrm{A} 12^{\mathrm{T}}\right) ; 2$, Ectothiorhodospira haloalkaliphila; 3, Ectothiorhodospira shaposhnikovii; 4, Ectothiorhodospira vacuolata; 5, Ectothiorhodospira mobilis; 6, Halorhodospira halophila; and 7, Thiorhodovibrio winogradskyi. All species were motile and the colour of all cell suspensions was red. All species utilized sulfide, sulfur, acetate and pyruvate. None of the species used formate, methanol, ethanol, citrate or benzoate. o, Not tested or no data available; $(+)$, weak growth.

\begin{tabular}{|c|c|c|c|c|c|c|c|}
\hline Character & 1 & 2 & 3 & 4 & 5 & 6 & 7 \\
\hline Type strain & ATCC $700588^{\mathrm{T}}$ & ATCC $51935^{\top}$ & DSM $243^{\mathrm{T}}$ & DSM $2111^{\mathrm{T}}$ & $\operatorname{DSM} 237^{\mathrm{T}}$ & DSM $244^{T}$ & $\mathrm{SSPI}^{\mathrm{T}}$ \\
\hline Cell diameter $(\mu \mathrm{m})$ & $3-4$ & $0.7-1 \cdot 2$ & $0.8-0.9$ & 1.5 & $0 \cdot 7-1 \cdot 0$ & $0.6-0.9$ & 1.4 \\
\hline Type of flagellation & Monopolar tuft & Monopolar tuft & Monopolar tuft & Monopolar tuft & Monopolar tuft & Bipolar tuft & $\begin{array}{l}\text { Monopolar } \\
\text { monotrichous }\end{array}$ \\
\hline $\mathrm{NaCl}$ optimum $(\%)$ & $0 \cdot 5-1 \cdot 0$ & 5 & 3 & $1-6$ & $2-3$ & $11-32$ & $2 \cdot 2-3 \cdot 2$ \\
\hline Salinity range $(\%)$ & & $2 \cdot 5-15$ & $0-7$ & $0.5-10 \cdot 0$ & $1-5$ & & \\
\hline $\mathrm{pH}$ optimum & $8 \cdot 5-9 \cdot 5$ & $8 \cdot 5-10 \cdot 0$ & $8 \cdot 0-8 \cdot 5$ & $7 \cdot 5-9 \cdot 5$ & $7 \cdot 6-8 \cdot 0$ & $8 \cdot 5-9 \cdot 0$ & $7 \cdot 0-7 \cdot 4$ \\
\hline Chemolithotrophic growth & - & + & + & o & - & - & + \\
\hline Sulfate assimilation & o & + & + & - & + & - & - \\
\hline \multicolumn{8}{|l|}{ DNA G $+\mathrm{C}$ content $(\mathrm{mol} \%)$} \\
\hline Range & $56 \cdot 0-57 \cdot 4$ & $62 \cdot 2-63 \cdot 5$ & $62 \cdot 0-64 \cdot 0$ & $61 \cdot 4-63.6$ & $67 \cdot 3-68 \cdot 4$ & $66 \cdot 5-69 \cdot 7$ & $61 \cdot 0$ \\
\hline Type strain* & $56 \cdot 0-57 \cdot 4$ & $63.5\left(T_{\mathrm{m}}\right)$ & $62 \cdot 0\left(T_{\mathrm{m}}\right)$ & $63 \cdot 6\left(T_{\mathrm{m}}\right)$ & $67 \cdot 3(\mathrm{Bd})$ & $68 \cdot 4(\mathrm{Bd})$ & $61 \cdot 0(\mathrm{Ca})$ \\
\hline \multicolumn{8}{|l|}{ Substrates utilized: } \\
\hline Hydrogen & o & 0 & + & + & + & 0 & o \\
\hline Thiosulfate & - & + & + & + & + & + & - \\
\hline Sulfite & o & o & + & o & + & - & o \\
\hline Propionate & + & o & + & + & + & + & + \\
\hline Butyrate & - & o & + & - & - & - & - \\
\hline Lactate & - & o & + & - & - & + & - \\
\hline Fumarate & + & + & + & + & + & + & - \\
\hline Succinate & + & + & + & + & + & + & - \\
\hline Malate & + & + & + & + & + & + & - \\
\hline Fructose & - & - & + & $(+)$ & + & - & - \\
\hline Glucose & - & - & 0 & - & + & - & - \\
\hline Ethanol & - & - & - & - & - & - & - \\
\hline Propanol & 0 & - & - & - & - & 0 & - \\
\hline
\end{tabular}

* $T_{\mathrm{m}}$, determined by thermal denaturation; $\mathrm{Bd}$, determined by buoyant density; Ca, determined by chemical analysis.

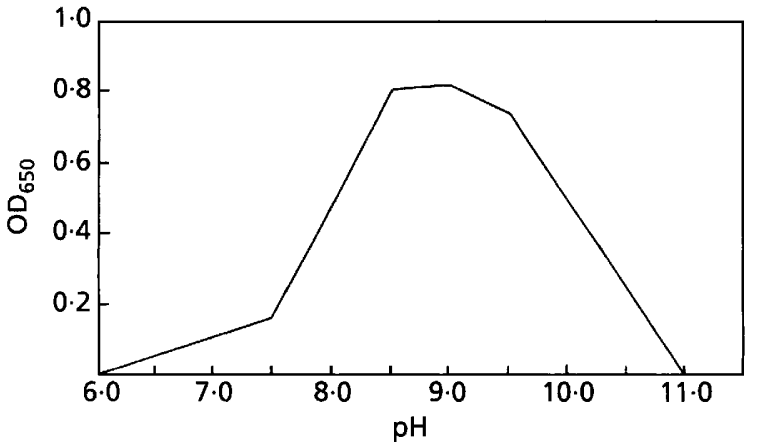

Fig. 5. Influence of $\mathrm{pH}$ on the growth of strain $\mathrm{A} 12^{\mathrm{T}}$.

by rhodopin $(31.5 \%)$, spirilloxanthin $(21.8 \%)$, didehydrorhodopin $(6 \cdot 5 \%)$ and lycopene $(2 \cdot 7 \%)$.

\section{Physiological properties}

Photolithoautotrophic growth occurred under anoxic conditions in the light with hydrogen sulfide, elemental sulfur and polysulfide as electron donors (Table 1). Thiosulfate was not used for phototrophic growth. During growth on sulfide, elemental sulfur was transiently formed, as could be visualized by the formation of globules of elemental sulfur, which were oxidized further to sulfate as the final oxidation product. In the

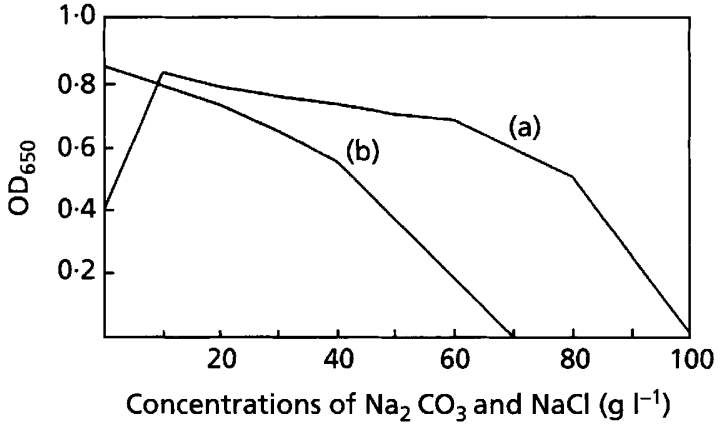

Fig. 6. Influence of concentrations of soda $\left(\mathrm{Na}_{2} \mathrm{CO}_{3}\right)(\mathrm{a})$ and $\mathrm{NaCl}$ (b) on growth of strain $\mathrm{A} 12^{\top}$.

presence of sulfide and bicarbonate, acetate, pyruvate, propionate, succinate, fumarate and malate were used as organic substrates for phototrophic growth of strain $\mathrm{A} 12^{\mathrm{T}}$. Ascorbate, arginine, aspartate, butyrate, benzoate, valerate, Casamino acids, glycerol, glycolate, glucose, gluconate, glutamate, yeast extract, caprylate, caproate, lactate, malonate, mannitol, methanol, sorbitol, tartrate, formate, fructose, citrate and ethanol were not photoassimilated. Growth under oxic or micro-oxic conditions was not possible, neither autotrophically nor in the presence of organic compounds. Growth factors were not required. 


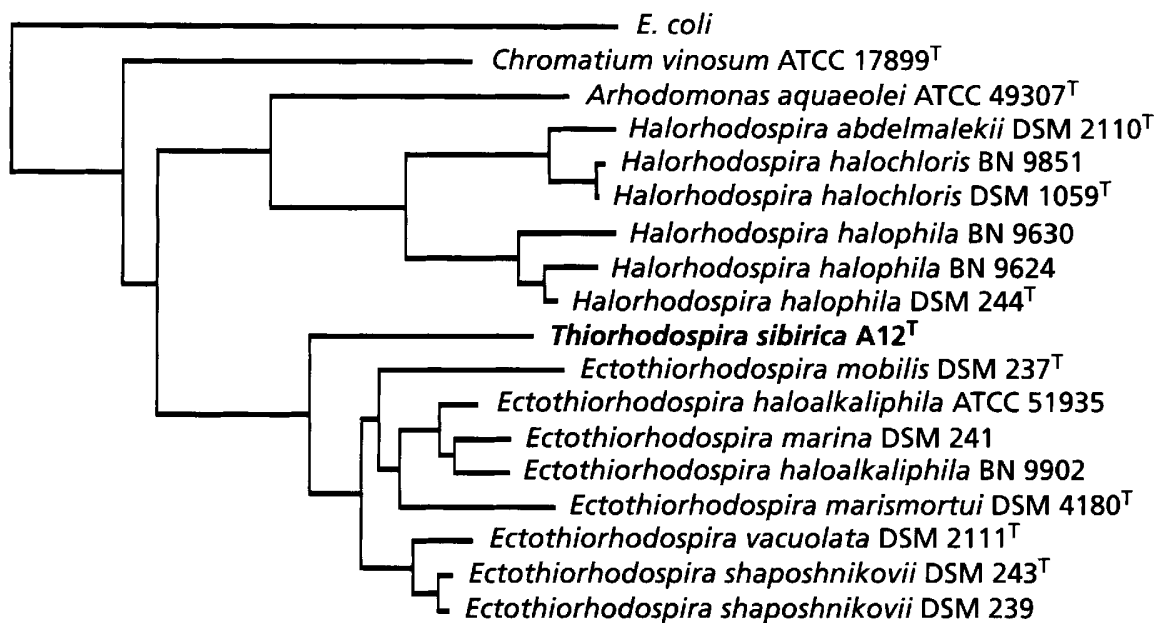

$0.05 K_{\text {nuc }}$
Fig. 7. Phylogenetic relatedness of strain $A 12^{\top}$ to other purple sulfur bacteria based on $16 \mathrm{~S}$ rDNA sequence comparison as indicated in Methods and outlined by Imhoff et al. (1998).
Optimum growth was observed at $\mathrm{pH} 8 \cdot 5-9 \cdot 5$ (Fig. 5) and $25-30^{\circ} \mathrm{C}$. No growth occurred at $\mathrm{pH} 7.0$ and slow growth was observed at $\mathrm{pH} 7.5$ with alkalinization of the medium. The bacterium grew well in medium containing $5 \mathrm{~g}$ sodium bicarbonate $\mathrm{l}^{-1}$ and tolerated up to $80 \mathrm{~g}$ sodium bicarbonate $1^{-1}$ or $60 \mathrm{~g}$ sodium chloride $1^{-1}$ (Fig. 6). Therefore, strain $\mathrm{A} 12^{\mathrm{T}}$ is considered to be alkaliphilic and halotolerant.

\section{Genetic relationship within the purple sulfur bacteria}

The comparison of the 16S rDNA sequence of strain $\mathrm{A} 12^{\mathrm{T}}$ with those from other purple sulfur bacteria revealed that this bacterium belongs to the Ectothiorhodospiraceae and within this family is distantly related to species of the genus Ectothiorhodospira. The 16S rDNA sequence from Thiorhodospira sibirica was most similar to sequences from Ectothiorhodospira shaposhnikovii and Ectothiorhodospira vacuolata (94.4-94.6\%; Fig. 7). The similarity values to other Ectothiorhodospira species were 91.7-93.5\%. The DNA G + C composition of strain $A 12^{\mathrm{T}}$ was $56 \cdot 0-57 \cdot 4$ mol $\%$, which is significantly lower than that observed in Ectothiorhodospira species (61.4-68.4 mol\%; Imhoff, 1989). It appears justified, therefore, that strain $\mathrm{A} 12^{\mathrm{T}}$ should be regarded as a new purple sulfur bacterium belonging to a new genus and species of the family Ectothiorhodospiraceae. The name Thiorhodospira sibirica gen. nov., sp. nov. is proposed.

\section{DISCUSSION}

The new purple sulfur bacterium Thiorhodospira sibirica is a typical member of the thiophilic littoral communities developing in low salinity, alkaline soda lakes in the steppe of south-east Siberia. Previously, the mass development of purple sulfur bacteria was observed in soda lakes of the Kulundinskaya steppe at $\mathrm{pH}$ above 10.0 (Isachenko, 1951). However, these purple sulfur bacteria were of smaller size than Thiorhodospira sibirica and, as Isachenko noted, were highly tolerant to oxygen. Being a strict anaerobe,
Thiorhodospira sibirica developed in ecosystems with high hydrogen sulfide production, particularly in layers of seasonal microbial mats and on the surface of decaying plant and algal biomass in the near-shore area of the lakes. In such habitats, Thiorhodospira sibirica was usually present in lesser numbers than other halotolerant, rod-shaped or coccoid purple sulfur bacteria. Our data indicate that Thiorhodospira sibirica requires small amounts of sodium ions, present as sodium carbonate and in addition, depending on the concentration of this salt, sodium chloride. Because of its dependence on low concentrations of sodium salts with an extended tolerance of sodium carbonate and sodium chloride, it can be regarded as a slightly halophilic bacterium being moderately halo- and sodatolerant.

The new isolate preferred to grow at $\mathrm{pH} 8 \cdot 5-10 \cdot 0$ and developed in alkaline brackish water bodies. The ability to grow slowly at $\mathrm{pH} 7.5$ was due to the alkalinization of the medium to $\mathrm{pH} 7 \cdot 7-8.0$ that occurred during growth. Therefore, the new bacterium appears to be an obligate alkaliphile, similar to other members of the Ectothiorhodospiraceae.

Thiorhodospira sibirica has a distinctive morphology and a lamellar intracytoplasmic membrane system, which is different from other species of the purple sulfur bacteria. The lamellae are not arranged in a regular stack-like order as in known Ectothiorhodospira species. Peripheral and circular lamellar membrane structures similar to those of Thiorhodospira sibirica were described in Rhodocista centenaria (Rhodospirillum centenum; Favinger et al., 1989) and in some rod-shaped budding purple nonsulfur bacteria such as Rhodopseudomonas palustris and Rhodomicrobium vannielii (parallel, non-circular membranes underlying the cytoplasmic membrane; see Pfennig \& Trüper, 1974).

Photosynthetic pigments of Thiorhodospira sibirica are bacteriochlorophyll $a$ and carotenoids of the spirilloxanthin series with anhydrorhodovibrin, rhodopin 
and spirilloxanthin as the dominant components, which are not uncommon among the phototrophic purple bacteria. Quite unusual among the purple sulfur bacteria are the in vivo absorption spectra of intact cells that show four maxima of bacteriochlorophyll $a$ in the near-IR region, all of comparable size, at 799 , 830,858 and $901 \mathrm{~nm}$. Most other purple sulfur bacteria with a complete set of light-harvesting complexes have three absorption maxima at around 800,850 and $870-880 \mathrm{~nm}$ (Sidorova et al., 1998). Only a few species were reported to exhibit a maximum at $820-830 \mathrm{~nm}$ with a concomitant disappearance of the band at 850 $\mathrm{nm}$, mostly caused by drastic changes in the cultivation conditions, e.g. by a decrease in the light intensity. Those species that form both complexes at the same time, such as Chromatium vinosum and Ectothiorhodospira species have a clear preference for the formation of one of these complexes and the presence of the other normally can be detected only in second derivative spectra (J. F. Imhoff, unpublished results).

Thiorhodospira sibirica cannot grow in the dark in the presence of oxygen. When growing photolithoautotrophically, the bacterium utilizes hydrogen sulfide but cannot use thiosulfate. This property is mostly inherent in strictly anaerobic purple sulfur bacteria. During oxidation of sulfide, sulfur globules accumulated and then gradually disappeared in the process of further growth. They are seen in the medium, attached to cells and also within the cells. Careful inspection revealed that sulfur globules are located in the peripheral periplasmic part of the cells and not in the space occupied by the cytoplasm of Thiorhodospira sibirica. It is therefore not easy to determine whether sulfur is formed inside or outside the cells or both. So far, microscopic inspection has allowed a clear distinction between Chromatiaceae and Ectothiorhodospiraceae with visible sulfur globules either in the body of the cells or outside of them. This easy and clear distinction is obscured by the properties of the new bacterium. The distinction between intracytoplasmic and extracytoplasmic elemental sulfur deposition already appeared to be disturbed by the finding that in Chromatium vinosum, which visibly deposits sulfur inside the cells, transport of the sulfur across the cytoplasmic membrane and deposition in the extracytoplasmic space has been supposed (Pattaragulwanit et al., 1998). In this regard, it is also of interest that Thiocystis gelatinosa (a species of the Chromatiaceae) is known to deposit the sulfur globules in the peripheral part of the cells, but is considered to deposit the sulfur within the cells (Pfennig \& Trüper, 1974). Thus, the distinction between extracellular and intracellular deposition and the distinction of the Ectothiorhodospiraceae and Chromatiaceae families on this basis is fading. It could well be that future work will show that a clear differentiation between internal and external deposition is not possible or that much more sophisticated work is necessary to do so. An emendation of the family descriptions should await more specific information on this aspect.
On the basis of its 16S rDNA sequence Thiorhodospira sibirica clearly affiliates with the Ectothiorhodospiraceae family. It appears to be specifically but distantly related to the genus Ectothiorhodospira, which is shown in sequence similarities to species of this genus of $91 \cdot 7-94.6 \%$. The low $\mathrm{G}+\mathrm{C}$ content in the DNA of Thiorhodospira sibirica (56.0-57.4 mol \%), which is significantly different from that in Ectothiorhodospira species, supports this view.

\section{Description of Thiorhodospira gen. nov.}

Thiorhodospira. (Thi.o.rho.do.spi'ra. Gr. n. thios sulfur; Gr. n. rhodon the rose; Gr. n. spira spiral; M.L. fem. $\mathrm{n}$. Thiorhodospira the spiral rose with sulfur).

Cells are vibrioid- or spiral-shaped, multiply by binary fission and are motile by means of a monopolar flagellar tuft. They are Gram-negative and belong to the $\gamma$-Proteobacteria. Internal membranes are of the lamellar type. Photosynthetic pigments are bacteriochlorophyll $a$ and carotenoids. Phototrophic growth occurs under anoxic conditions. The metabolism is strictly anaerobic and obligately phototrophic. During photolithoautotrophic growth with sulfide as electron donor, globules of elemental sulfur are transiently stored outside the cytoplasm. Microscopic examination locates these globules in the medium, attached to the cells or within the cellular body. The final oxidation product is sulfate. In the presence of sulfide, organic substances may be photoassimilated. Development is dependent on sodium salts in low concentrations and on alkaline conditions. The habitat of the bacterium is the surface of sediments rich in organic matter and microbial mats of brackish soda lakes containing hydrogen sulfide. The DNA G + C content is $56 \cdot 0-57 \cdot 4$ mol \% (melting temperature method). The type species of the genus is Thiorhodospira sibirica sp. nov.

\section{Description of Thiorhodospira sibirica sp. nov.}

Thiorhodospira sibirica. (si.bi'ri.ca. M.L. fem. n. sibirica related or belonging to Siberia).

Cells are vibrioid- or spiral-shaped, 3-4 $\mu \mathrm{m}$ wide and 7-20 $\mu \mathrm{m}$ long and multiply by binary fission with formation of septa. They are motile by means of a monopolar tuft of flagella, which usually approximates the length of the cells. Internal membranes are parallel lamella piercing lengthways the cytoplasm or underlying the cytoplasmic membrane. Colour of cell suspensions is brownish-red to red. Intact cell suspensions show absorption maxima at $377,485,509$, $537-550,591,711,799,830,858$ and $901 \mathrm{~nm}$. Photosynthetic pigments are bacteriochlorophyll $a$ and carotenoids of the spirilloxanthin series, with anhydrorhodovibrin, rhodopin and spirilloxanthin as major components. Metabolism is strictly anaerobic and obligately phototrophic. Photolithoautotrophic growth occurs with sulfide and sulfur as electron donors. Thiosulfate is not oxidized. In the presence of sulfide and carbonates, acetate, pyruvate, malate, 
succinate, propionate and fumarate are photoassimilated. Mesophilic and alkaliphilic brackish water bacterium with optimum growth at $\mathrm{pH} 9 \cdot 0-9.5(\mathrm{pH}$ range $7 \cdot 5-10 \cdot 5)$ and $25-30^{\circ} \mathrm{C}$. Requires sodium carbonate and/or sodium chloride for growth and is alkaliphilic and halotolerant. Salinity range is $5-80 \mathrm{~g}$ sodium bicarbonate $1^{-1}$, or $0-60 \mathrm{~g}$ sodium chloride $\mathrm{l}^{-1}$ (in the presence of $5 \mathrm{~g}$ sodium carbonate $1^{-1}$ ). Habitat is sulfide-containing surface layers of the Lake Malyi Kasytui sediment. The DNA G $+\mathrm{C}$ of the type strain is $56.0-57.4 \mathrm{~mol} \%$ (melting temperature method). The type strain is ATCC $700588^{\mathrm{T}}$ (Gorlenko: $\mathrm{A} 12^{\mathrm{T}}$ ).

\section{ACKNOWLEDGEMENTS}

The authors thank A. M. Lysenko for determination of the DNA G + C content, Z. K. Mahneva and A. A. Moskalenko for carotenoid analysis, and F. Lappe for 16S rDNA sequence analysis. The study was supported by a research grant on Biodiversity and by grant 96.04 .48466 from the Russian Foundation for Basic Research.

Dodgson, K. S. (1961). Determination of inorganic sulphate in studies on the enzymatic and nonenzymatic hydrolysis of carbohydrate and other sulphate esters. Biochem J 78, 312-329.

Favinger, J., Stadtwald, R. \& Gest, H. (1989). Rhodospirillum centenum, sp. nov., a halotolerant cyst-forming anoxygenic photosynthetic bacterium. Antonie Leeuwenhoek 55, 291-296.

Felsenstein, J. (1989). PHYLIP, phylogenetic inference package (version 3.2). Cladistics 5, 164-166.

van Gemerden, H. \& Mas, J. (1995). Ecology of phototrophic sulfur bacteria. In Anoxygenic Photosynthetic Bacteria, pp. 49-85. Edited by R. E. Blankenship, M. T. Madigan \& C. E. Bauer. The Netherlands: Kluwer.

Gorlenko, V. M., Dubinina, G. A. \& Kusnetsov, S. I. (1983). The ecology of aquatic microorganisms (monograph). In Binnengewässer, pp. 254. Edited by W. Ohle. Stuttgart: Schweizerbartsche Verlagsbuchhandlung.

Imhoff, J. F. (1984). Reassignment of the genus Ectothiorhodospira Pelsh 1936 to a new family, Ectothiorhodospiraceae fam. nov., and emended description of the Chromatiaceae Bavendamm 1924. Int J Syst Bacteriol 34, 338-339.

Imhoff, J. F. (1989). The genus Ectothiorhodospira. In Bergey's Manual of Systematic Bacteriology, vol. 3, pp. 1654-1658. Edited by J. T. Staley, M. P. Bryant, N. Pfennig \& J. G. Holt. Baltimore: Williams \& Wilkins.

Imhoff, J. F. (1992). Taxonomy, phylogeny and general ecology of anoxygenic phototrophic bacteria. In Biotechnology Handbook of Photosynthetic Prokaryotes, pp. 53-92. Edited by N. G. Carr \& N. H. Mann. London \& New York: Plenum.

Imhoff, J. F. (1995). Taxonomy and physiology of phototrophic purple bacteria and green sulfur bacteria. In Anoxygenic Photosynthetic Bacteria, pp. 179-205. Edited by R. E. Blankenship, M. T. Madigan \& C. E. Bauer. The Netherlands: Kluwer. Imhoff, J. F. \& Süling, J. (1996). The phylogenetic relationship among Ectothiorhodospiraceae. A re-evaluation of their taxonomy on the basis of 16S rDNA analyses. Arch Microbiol 165, 106-113.
Imhoff, J. F., Sahl, H. G., Soliman, G. S. H. \& Truper, H. G. (1979). The Wadi Natrun: chemical composition and microbial mass developments in alkaline brines of eutrophic desert lakes. Geomicrobiology J 1, 219-234.

Imhoff, J. F., Süling, J. \& Petri, R. (1998). Phylogenetic relationships among the Chromatiaceae, their taxonomic reclassification and description of the new genera Allochromatium, Halochromatium, Isochromatium, Marichromatium, Thiococcus, Thiohalocapsa, and Thermochromatium. Int J Syst Bacteriol 48, 1129-1143.

Isachenko, B. L. (1951). Chloride, sulfate and soda lakes of the Kulundinskaya steppe. Izbrannye Trudy Nauka 2, 143-162.

Jukes, T. H. \& Cantor, C. R. (1969). Evolution of protein molecules. In Mammalian Protein Metabolism, pp. 21-132. Edited by H. M. Munro. New York: Academic Press.

Marmur, J. (1961). A procedure for the isolation DNA from microorganisms. J Molecular Biol 3, 208-218.

van Niel, C. B. (1931). On the morphology and physiology of the purple and green sulphur bacteria. Arch Mikrobiol 3, 1-112.

Owen, R. J., Hill, L. R. \& Lapage, S. P. (1969). Determination of DNA base composition from melting profiles in dilute buffers. Biopolymers 7, 503-516.

Pattaragulwanit, K., Brune, D. C., Trüper, H. G. \& Dahl, C. (1998). Molecular genetic evidence for extracytoplasmic localization of sulfur globules in Chromatium vinosum. Arch Microbiol 169, 434444.

Pfennig, N. \& Truper, H. G. (1974). The phototrophic bacteria. In Bergey's Manual of Determinative Bacteriology, 8th edn, pp. 24-75. Edited by R. E. Buchanan \& N. E. Gibbons. Baltimore: Williams \& Wilkins.

Ryter, A. \& Kellenberger, E. (1958). Etude au microscope electronique des plasmes contenant de l'acide deoxyribonucleique. 1. Les nucleotides des bacteries en croissance active. $Z$ Naturforsch 13b, 597-605.

Sanger, F., Nicklen, S. \& Coulson, A. R. (1977). DNA sequencing with chain-termination inhibitors. Proc Natl Acad Sci USA 74, 5463-5467.

Sidorova, T. N., Makhneva, Z. K., Puchkova, N. N., Gorlenko, V. M. \& Moskalenko, A. A. (1998). Characteristics of photosynthetic apparatus of Thiocapsa strain BM3 containing okenone as the main carotenoid. Mikrobiologiya 67, 199-206.

Stackebrandt, E., Murray, R. G. E. \& Truper, H. G. (1988). Proteobacteria classis nov., a name for the phylogenetic taxon that includes the 'purple bacteria and their relatives'. Int J Syst Bacteriol 38, 321-325.

Thompson, J. D., Higgins, D. G. \& Gibson, T. J. (1994). CLUSTAL $\mathrm{W}$ : improving the sensitivity of progressive multiple sequence alignment through sequence weighting position-specific gap penalties and weight matrix choice. Nucleic Acids Research 22, 4673-4680.

Truper, H. G. \& Schlegel, H. G. (1964). Sulphur metabolism in Thiorhodaceae. 1. Quantitative measurements of growing cells of Chromatium okenii. Antonie Leeuwenhoek J Microbiol Serol 30, 225-238.

Winogradsky, S. (1888). Zur Morphologie und Physiologie der Schwefelbakterien. In Beiträge zur Morphologie und Physiologie der Bakterien, Heft 1. Leipzig: Felix.

Woese, C. R., Weisburg, W. G., Hahn, C. M., Paster, B. J., Zablen, L. B., Lewis, B. J., Macke, T. J., Ludwig, W. \& Stackebrandt, E. (1985). The phylogeny of purple bacteria: the gamma subdivision. Syst Appl Microbiol 6, 25-33. 